\title{
DPF3 Gene
}

National Cancer Institute

\section{Source}

National Cancer Institute. DPF3 Gene. NCI Thesaurus. Code C157310.

This gene is involved in neuron-specific chromatin remodeling. 